\title{
DESA ADAT SEBAGAI PEMBENTUK DISIPLIN DAN PEMERSATU KRAMA DESA
}

\author{
Ni Luh Ketut Sukarniti
}

Jurusan Ilmu Administrasi Negara

Fakultas Ilmu Sosial dan Ilmu Politik, Universitas Mahendradatta, Denpasar

J1. Ken Arok No. 12, Peguyangan Denpasar

E-mail: sukarnitiagung02@gmail.com

\begin{abstract}
Abstrak - Penerapan UU No. 6 Tahun 2014 tentang Desa diharapkan tidak mematikan eksistensi Desa Adat. Struktur kepengurusan desa adat di Bali intinya terdiri dari Bendesa Adat atau Kelihan Adat dan Kelihan Banjar Adat dan semua para pembantunya disebut sebagai Prajuru Kata "juru" dalam bahasa Bali artinya "tukang" atau "petugas".

Tata cara pemilihan Prajuru Desa Adat sesuai ketentuan awig-awig Desa Adat tidak selalu seragam antara Desa Adat satu dengan yang lainnya. Pada umumnya, pemilihan prajuru desa adat melalui sangkepan (rapat) desa yang diselenggarakan khusus untuk itu. Bagi desa adat yang warganya sedikit, pemilihan dilakukan secara langsung dengan menyebutkan nama-nama calon yang diajukan, kemudian diminta persetujuan dari peserta sangkepan. Bagi desa yang terdiri dari beberapa banjar, pemilihan biasanya dilakukan melalui sangkepan para kelihan banjar dan pada sangkepan itu para kelihan banjar menyampaikan nama-nama calon yang diajukan oleh banjarnya masing-masing, jika memang ada. Apabila telah diperoleh kata sepakat tentang nama-nama yang dicalonkan, susunan prajuru dan pembagian tugasnya, maka pada hari sangkepan itu juga para calon terpilih disahkan sebagai Prajuru Desa Adat.

Adapun nama-nama jabatan dalam Prajuru Desa Adat, pada umumnya terdiri dari Bendesa Adat/Kelihan Desa Adat sebagai pimpinan tertinggi, Penyarikan (Sekretaris), Petengen (Bendahara), Kesinoman (Juru Arah) dan pada anggota prajuru lainnya yang diadakan menurut kebutuhan desa dan diberikan nama menurut kebiasaan di desa adat bersangkutan. Fungsi utama Desa Adat adalah memelihara, menegakkan dan memupuk adat-istiadat yang diterima secara turun temurun di desa adat itu sendiri.
\end{abstract}

Kata kunci: Desa Adat, Pembentuk Disiplin dan Pemersatu Krama Desa.

\section{PENDAHULUAN}

Sesuai dengan Peraturan Pemerintah Daerah Provinsi Bali Undang - Undang Nomor 23 Tahun 2014 tentang kedudukan, fungsi dan peranan Desa Adat memberikan penegasan tentang pengertian Desa Adat sebagai berikut : " Desa Adat adalah kesatuan masyarakat hukum adat yang mempunyai satu kesatuan tradisi dan tata krama pergaulan hidup masyarakat Hindu secara turun temurun dalam ikatan Kahyangan Tiga ( Kahyangan Desa ) yang mempunyai wilayah tertentu dan harta kekayaan sendiri serta berhak mengurus rumah tangganya sendiri”.

Menurut Peraturan Menteri Dalam Negeri Nomor 03 Tahun 1997 tentang pemberdayaan dan pelestarian serta pengembangan adat istiadat kebiasaan - kebiasaan masyarakat dan lembaga adat di daerah menegaskan sebagai berikut : " Lembaga Adat adalah sebuah organisasi kemasyarakatan baik yang sengaja dibentuk maupun yang secara tumbuh berkembang di dalam suatu masyarakat hukum adat tertentu dengan wilayah hukum dan hak atas harta kekayaan di dalam wilayah hukum tersebut serta berhak dan berwenang untuk mengatur serta mengurus dan menyelesaikan permasalahan kehidupan yang terkait dan mengacu pada adat istiadat dan hukum adat yang berlaku".

Dari kedua sumber hukum tersebut di atas, dapat ditarik beberapa kesimpulan antara lain:

1. Pengakuan terhadap Desa Adat sebagai organisasi kemasyarakatan yang berhak mengurus rumah tangganya sendiri (otonomi). 
2. Secara normatif kedudukan dan keberadaan Desa Adat sangat kuat dan jelas dasar hukumnya.

3. Sesuai Peraturan Menteri Dalam Negeri Nomor 03 Tahun 1997 secara tegas tentang Kewajiban Gubernur/Bupati/Walikota untuk membantu tersedianya sarana dan prasarana serta dalam setiap tahun anggaran menyediakan dana melalui Anggaran Pendapatan Belanja Negara (APBD) sesuai kemampuan daerah.

Prospek keberadaan Desa Adat sebagai Desa Otonom adalah sangat cerah, namun ditinjau dari realitas sosial pemberdayaan dana pengembangan Desa Adat di Bali dihadapkan kepada berbagai masalah/kendala, tantangan sekaligus peluang diera globalisasi dan reformasi dewasa ini dengan berbagai perubahan tentang peraturan perundang - undangan mengenai peraturan pemerintahan di daerah.

Mengenai peraturan - peraturan daerah yang akan mengalami beberapa perubahan tidak akan mengurangi otonomi Desa Adat itu sendiri apalagi keberadaan Desa Adat akan tetap lestari dan ditingkatkan pemberdayaannya ditinjau dari faktor sumber daya manusia yang mampu menghadapi segala perkembangan kemajuan jaman.

Apabila para Prajuru Desa Adat sudah menghayati peraturan-peraturan yang tertuang dalam Awig - Awig Desa Adat maka segala tugas dan kewajiban Prajuru akan dapat dilaksanakan sebaik-baiknya tanpa banyak mengalami hambatan /kendala sehingga semuanya berjalan lancar. Awig - awig Desa Adat merupakan peraturan dan ketentuan dasar yang dibuat Krama Desa Adat itu sendiri dan dijadikan pedoman perilaku kramanya. Awig - awig itu mengatur dan mengarahkan Krama Desa dalam kehidupan bermasyarakat sehingga terbentuklah disiplin yang tinggi dan menjadi pegangan serta pedoman dalam menyelesaikan permasalahan / persengketaan yang timbul di antara Krama Desa itu sendiri. Awig - awig merupakan penjabaran lebih nyata dari Tri Hita Karana karena dengan jelas diuraikan tentang Sukerta Tata Parahyangan, Sukerta Tata Pawongan dan Sukerta Tata Palemahan sebagai berikut:

1. Sukerta Tata Parhyangan adalah peraturan dan ketentuan yang menjadi dasar atau pedoman perilaku hubungan Krama Desa dengan Hyang Widhi Wasa yang menyangkut sikap spiritual secara patuh.

2. Sukerta Tata Pawongan adalah peraturan dan ketentuan yang menjadi dasar atau pe- doman bertingkah laku hubungan sesama Krama Desa.

3. Sukerta Tata Palemahan adalah merupakan aturan dan ketentuan yang menjadi dasar atau pedoman berperilaku hubungan Krama Desa dengan alam sekitarnya termasuk lingkungan hidup.

Dari pelaksanaan Awig-awig Desa itu akan dapat membentuk disiplin Krama/masyarakat karena yang melanggar dikenakan sanksi secara mendidik dan sekaligus akan dapat mewujudkan persatuan dan kesatuan dalam masyarakat.

\section{PEMBAHASAN}

\section{Awig-Awig Sebagai Pembentuk Disiplin}

Setiap Desa Adat telah memiliki awig-awig baik secara tertulis maupun tidak tertulis sejak Desa Adat itu ada atau dibentuk untuk mengatur dan mengarahkan pola perilaku Krama Desa/anggotanya dalam kehidupan bermasyarakat serta menjadi pedoman dalam menyelesaikan sengketa di antara Krama Desa atau diantara Krama Desa dengan Desa Adat itu sendiri. Di dalam membina dan membenahi Adat dan Desa Adat diperlukan suatu sikap berhati-hati dan penuh dengan kebijaksanaan. Kesabaran, keluwesan, kejujuran dan contoh ulah perilaku yang baik dan benar dari pemuka Desa Adat, akan membantu upaya mewujudkan hasil pembinaan yang diharapkan.

Membina Desa Adat dan adat - istiadat mencakup pengertian menata kembali suatu kehidupan Desa Adat dan adat-istiadat itu sendiri kea rah yang lebih baik. Dalam upaya ini sudah tentu ada beberapa hambatan yang patut dilewati dengan penuh bijaksana dan menghindari kegoncangan yang mungkin timbul antara lain disebabkan bergesernya tata nilai dalam kehidupan masyarakat. Untuk dapat lebih efektifnya usaha-usaha itu maka kewibawaan Desa Adat dan Lembaga Adat perlu dijaga. Petunjuk-petunjuk dari pimpinan Desa Adat dan keputusan-keputusan yang diambil atas dasar kesepakatan bersama, hendaknya konstruktif dan obyektif, patut dihormati dan ditaati oleh seluruh Krama Desa.

Apabila kondisi yang demikian itu dapat diwujudkan, maka ketertiban masyarakat akan tercapai. Ketertiban akan terwujud, apabila segenap Krama Desa memiliki rasa disiplin hidup bermasyarakat. Bilamana disiplin hidup bermasyarakat dapat ditegakkan dalam arti bukan disiplin mati, maka kokohlah Desa Adat dan ampuhlah adat istiadat itu. Kesemuanya 
itu menuntut suatu peningkatan hidup bermasyarakat.

Sehubungan dengan itu, para pemuka Desa Adat dan Pemimpin Lembaga Adat, diharapkan banyak memberi contoh yang baik serta benar dan menjadikan dirinya pola panutan dalam tata krama hidup di masyarakat. Patutlah disadari bahwa adat juga berfungsi mendidik yang bersifat pendidikan non formal. Suatu metode yang baik dalam menterapkan pendidikan non formal di masyarakat adalah memberikan contoh yang patut ditiru dan dipercaya oleh masyarakat. Berbuat membenahi masyarakat dan menata kehidupan sosial budaya yang diproyeksikan ke dalam Desa Adat adalah suatu pengabdian yang bernilai tinggi. Kita menyadari bahwa kehidupan di hari esok, sangat tergantung kepada kehidupan hari ini. Karenanya upaya yang kita lakukan bersama membina Desa Adat dan adat istiadat guna menjaga kelestariannya adalah suatu perbuatan mulia. Kemuliaannya terletak pada arti pentingnya kita dapat beramal bakti bersama kepada masyarakat. Ini merupakan realisasi daripada falsafah Manusa Yadnya dalam agama Hindu. Dengan menyadari hal ini, maka jerih payah serta pengorbanan-pengorbanan yang dialami dalam berbakti kepada masyarakat akan memberikan arti tersendiri dalam kehidupan.

Dalam rangka membina Desa Adat dan adat istiadat di Bali, maka Majelis Pembina Lembaga Adat Daerah Tingkat I Bali, setiap tahun menyelenggarakan Pesamuhan Badan Pelaksana Pembina Lembaga Adat Kabupaten dan Kecamatan se-Bali dimulai sejak Tahun 1980. Sudah banyak hal-hal yang dibahas dan sudah banyak pula keputusan yang dihasilkan.

Memasyarakatkan hasil - hasil Pesamuhan Adat itu sangat penting dan saya mengharapkan kepada para Kelihan Desa/Bendesa agar ini dijadikan pegangan dalam membina Krama Desanya. Walaupun kita tetap menghormati adanya : desa mawa cara, sima dan dresta setempat, namun untuk kebersamaan dan untuk keseluruhan, diperlukan adanya pegangan bersama berupa prinsip-prinsip dasar dalam tata kehidupan Desa Adat yang maju, aman, tentram dan sejahtera. Kita tetap mempertahankan otonomi Desa Adat itu sendiri, namun aturan-aturan yang dibuat berdasarkan otonominya itu tidaklah boleh menyimpang dari norma - norma kemanusiaan dan peraturan perundang - undangan yang berlaku. Dengan langkah - langkah ini, kita berharap tidak ada permasalahan yang muncul di Desa Adat yang dapat menimbulkan keresahan

Majelis Pembina Lembaga Adat Provinsi Bali bersama-sama Badan Pelaksana Pembina Lembaga Adat Kabupaten /Kota telah mengadakan pembinaan secara terus-menerus sehingga pada gilirannya nanti semua Desa Adat di Bali memiliki awig-awig secara tertulis dengan dwi aksara dan memakai eka basa yaitu Bahasa Bali. Hal ini dimaksudkan agar segala pelaksanaan tugas-tugas senantiasa berpedoman kepada Awig - Awig yang merupakan suatu kebenaran yang lurus dan harus ditaati oleh semua Krama Desa Adat.

Awig-awig Desa Adat di Bali merupakan refleksi dari Pancasila dimana materi yang tertuang dalam awig-awig tersebut merupakan pencerminan dari nilai-nilai Pancasila seperti :

1. Mengatur tentang kewajiban anggota/krama kepada Kahyangan sebagai kehidupan berKetuhanan Yang Maha Esa.

2. Pengakuan akan harkat dan martabat yang sama sebagai anggota/krama.

3. Adanya kekompakan persatuan dan kesatuan sebagai anggota/krama.

4. Selalu bermusyawarah dalam paruman atau rapat - rapat desa.

5. Terdapat unsur keadilan dalam suka-duka kehidupan bermasyarakat serta diikat oleh kehidupan bersama dan saling gotong royong.

Adapun mengenai pengertian Awig-awig sebagai Hukum Adat dapat dibedakan menjadi 2 (dua) yakni hukum yang berasal dari atas dan Hukum yang berasal dari bawah.

Hukum yang berasal dari atas adalah dari Tuhan dapat berwujud Hukum Agama, Hukum Negara atau Pemerintah sedangkan Hukum yang berasal dari bawah adalah yang berasal dari masyarakat setempat yang populer disebut Hukum Adat. Pada masyarakat Bali Hukum Adat dikenal dengan istilah Awig-awig, disamping itu juga dikenal istilah Sima, Dresta, Gamacara dan Ugeruger. Secara umum istilah-istilah tersebut di atas, menunjuk pada satu pengertian tentang aturan - aturan bertingkah laku yang lahir dari perasaan keadilan dan rasa kepatutan yang dijiwai agama Hindu dalam kehidupan anggota masyarakat adat dalam mewujudkan keharmonisan dan keselarasan hubungannya dengan Tuhan, Manusia dan Alam sekitarnya.

Awig-awig bersumber pada Gama (Agama) dan Sima (Dresta) antara lain :

1. Gama atau Sastra Dresta adalah peraturan dasar atau aturan utama seperti istilah adigama, purwadigama, kutara Manawa dan 
lain - lain, yang kesemuanya merupakan petunjuk dasar yang harus dilaksanakan. Hukum Adat atau Awig - awig dalam pengertian agama menunjuk pada pengertian sekumpulan azas atau prinsip - prinsip Hukum yang bersifat umum dan sangat abstrak. Dalam tingkatan perundang - undangan Negara, Gama atau Agama dapat disamakan dengan kaidah fundamental seperti Pancasila dan Undang - Undang Dasar Tahun 1945 (UUD 1945) yang berlaku di Negara Republik Indonesia. Hukum Adat Bali dalam tingkatan Gama tersebut berisi kaidah - kaidah yang berasal dari ajaran agama Hindu yang akan dijabarkan lebih lanjut dalam aturan Hukum yang berada dibawahnya, sehingga dapat lebih dipahami serta dilaksanakan dalam kehidupan bermasyarakat secara teratur dan meyakinkan.

2. Sima atau Dresta yang terdiri dari Desa Dresta, Loka Dresta dan Purwa Dresta adalah Hukum Adat yang berisi ketentuan-ketentuan secara garis besarnya saja yang dapat disamakan dengan aturan pokok. Sima hanya mengatur hal-hal yang pokok seperti pasal-pasal atau Batang Tubuh Undang-Undang Dasar Tahun 1945.

Disamping pengertian Gama dan Sima ada lagi yang dinamakan Perarem yaitu keputusan paruman atau sangkepan yang berisi pelaksanaan lebih lanjut dari Gama dan Sima tersebut. Kedudukan Perarem dapat disamakan dengan Peraturan Pelaksanaan seperti Peraturan Pemerintah, Keputusan Presiden dan Keputusan Menteri.

Dengan demikian dapat disimpulkan bahwa Hukum Adat Bali atau Awig- awig dalam pengertian yang luas adalah Gama, Sima dan Perarem. Program Pembangunan Pemerintah dewasa ini banyak pelaksanaannya melalui Awig-awig dan ternyata dapat berjalan dengan lancar dan sukses seperti Keluarga Berencana (KB), Insus Pertanian, Wajib Belajar dan lainlain. Program Pembangunan itu sudah tentu tidak dapat dimasukkan ke dalam awig-awig menurut pengertian Sima yang memuat aturanaturan pokok saja, tetapi hal tersebut dapat diatur dalam Perarem untuk tidak mengadakan perubahan Awig-awig. Dengan diadakannya Perarem maka segala permasalahan yang timbul sesuai dengan perkembangan jaman dapat diatasi tanpa mengadakan perubahan Awig-awig yang sudah disahkan.

Apabila diperhatikan secara seksama maka pelaksanaan pembangunan yang diserahkan kepada Desa Adat atau Banjar semuan- ya dapat berjalan dengan lancar dan sukses akibat adanya rasa patuh dan taat pada Awig-awig Desa Adat. Krama Desa Adat yang tergabung dalam Banjar merasa terpanggil untuk memenuhi kewajibannya, sehingga terbentuklah suatu disiplin yang hidup dan berkembang serta dapat mewujudkan adanya keselarasan dan kerukunan yang nyata dalam pergaulan masyarakat Adat.

Pembentukan disiplin dalam masyarakat Adat ditandai dengan adanya kulkul di tiap-tiap Banjar/Desa Adat, apabila kulkul atau kentongan tersebut berbunyi maka Krama Desa akan datang berduyun-duyun ke Banjar. Setelah berkumpul maka prajuru Desa Adat segera mengarahkan anggotanya untuk melaksanakan tugasnya dan sebelumnya juga dicek kehadirannya oleh kasinoman.

Dari uraian di atas, dapat ditarik kesimpulan bahwa Desa Adat memiliki awig-awig baik yang tertulis maupun tidak mampu untuk membentuk disiplin para anggotanya secara spontan tanpa adanya unsur paksaan dari para prajuru atau Kelihan Desa. Sehingga disiplin itu hidup yang merupakan modal dasar untuk melaksanakan tugas-tugas pembangunan di masyarakat dan semuanya dapat berjalan dengan lancar serta sukses.

\section{Desa Adat Sebagai Pemersatu Krama}

Sebagaimana diketahui bahwa manusia akan dapat menikmati hidup apabila bersama-sama dengan manusia lainnya saling membantu untuk memenuhi kebutuhan hidupnya masing-masing sesuai dengan kodratnya.

Aristoteles seorang ahli filsafat Yunani yang juga muridnya Plato menyatakan bahwa manusia itu adalah Zoon Politicon yaitu mahluk yang selalu hidup bermasyarakat dan hidup senantiasa dalam hubungan dengan manusia lainnya. Secara sadar atau tidak manusia senantiasa membina, memelihara dan mengembangkan hubungan diantara sesame manusia.

Untuk dapat mewujudkan hubungan tersebut manusia bertempat tinggal bersama-sama di suatu tempat yang dapat memenuhi kebutuhan hidupnya masing-masing sebagai mahluk sosial yang selalu saling membutuhkan. Tuntutan kerja sama yang harmonis dengan sesame manusia dihadapkan pada situasi lingkungan hidup yang dinamis.

Mengenai tempat tinggal bersama yang dihuni oleh orang banyak disebut Desa yang memiliki beberapa unsur yaitu :

1. Sifat manusia sebagai mahluk sosial. 
2. Unsur kejiwaan manusia masing- masing.

3. Alam sekeliling manusia itu sendiri.

4. Kepentingan yang sama diantara sesama manusia.

5. Bahaya dari luar yang mengancam kehidupan manusia.

Berdasarkan uraian tersebut di atas, maka dapat dikatakan bahwa manusia cenderung membina, memelihara dan mengembangkan hubungan antara manusia yang pada akhirnya membentuk suatu kesatuan masyarakat yang menempati suatu wilayah tertentu yang disebut komunitas. Komunitas yang besar diberi nama Negara sedangkan yang kecil diberi nama Desa/Negari/Kampung/Rukun Tetangga dan sebagainya.

Di Bali terdapat Desa Dinas dan Desa Adat dimana keduanya mendapat pengakuan yang sama dari pemerintah tentang eksistensinya berdasarkan Undang - Undang (UU) dan Peraturan Daerah (Perda) serta Peraturan Menteri Dalam Negeri, sehingga kedua lembaga tersebut berfungsi mengatur anggota masyarakat sesuai dengan kewenangannya masing-masing. Desa Dinas mengatur pemerintah Desa dengan segala aspeknya, Desa Adat mengatur keberadaan Krama/Anggota masyarakat sesuai dengan Tri Hita Karana. Desa Adat sebagai kesatuan masyarakat, dimana rasa persatuan dan kesatuan sebagai Krama/ Warga Desa terikat oleh wilayah tertentu dengan batas-batas yang jelas dan terikat pula oleh suatu sistem tempat persembahyangan yang disebut Pura Kahyangan Tiga (Pura Desa, Pura Puseh dan Pura Dalem).

Dari uraian tersebut di atas, dapat ditarik kesimpulan bahwa unsur-unsur mutlak tentang adanya Desa Adat di Bali terdiri dari Parahyangan, Pawongan dan Palemahan yang dikenal sebagai konsep Tri Hita Karana yaitu adanya tiga penyebab yang mendatangkan kebahagiaan. Parahyangan (Pura) merupakan unsur spiritual religious, Pawongan sebagai unsur personal atau sumber daya manusia dan Palemahan sebagai unsur material atau unsur fisik dari suatu Desa Adat.

Dengan demikian Desa Adat merupakan organisasi khusus orang Bali yang memiliki aturan - aturan tertentu yang disebut Awig awig untuk mengatur segala sesuatu berkenaan dengan Parahyangan, Pawongan dan Palemahan sehingga terwujudlah suatu persatuan dan kesatuan sesama warga Desa (Krama Desa).

Berkenaan dengan keberadaan Pura (Kahyangan), Pawongan dan Palemahan dapat dijelaskan sebagai berikut: a. Pura (Kahyangan Tiga)

Desa Adat sebagai kesatuan masyarakat yang beragama Hindu dan sekaligus berfungsi sebagai lembaga yang mengkonsepsikan dan mengaktifkan interaksi sosial masyarakat Desa Adat, maka Pura Kahyangan Tiga merupakan salah satu unsur mutlak yang terdiri dari Pura Desa tempat memuja Dewa Brahma, Pura Puseh tempat memuja Dewa Wisnu dan Pura Dalem tempat memuja Dewa Siwa dimana ketiganya dikenal sebagai Tri Murti perwujudan Sang Hyang Widhi Wasa, Dewa Brahma sebagai pencipta (Utpatti), Dewa Wisnu sebagai pemelihara (Stiti), dan Dewa Siwa sebagai pelebur (Pralina). Ketiga Pura tersebut adalah sebagai unsur pengikat anggota masyarakat dalam suatu Desa Adat yang mencerminkan rasa persatuan dan kesatuan warga Desa Adat secara turun temurun. Dengan demikian maka dapat dikatakan bahwa Pura Kahyangan Tiga merupakan ciri utama dan sekaligus sebagai unsur mutlak yang bersifat spiritual religious.

\section{b. Pawongan}

Pawongan itu merupakan unsur mutlak yang kedua dari keberadaan Desa Adat di Bali yang terdiri dari Krama Desa dan Prajuru Desa Adat. Jadi yang dimaksud Krama Desa adalah orang yang bertempat tinggal di Palemahan Desa Adat dan memiliki ikatan Hukum dengan Desa Adat itu. Pada umumnya Krama Desa Adat dibedakan menjadi dua (2) yaitu Krama Pengarep dan Krama Pengele yang dibedakan hak dan kewajibannya. Krama Pengarep atau Pengayah adalah Krama Desa yang mempunyai hak dan kewajiban secara penuh sedangkan Krama Pengele atau Roban tidak memiliki hak dan kewajiban secara penuh.

Dalam era globalisasi sekarang ini perlu dipikirkan bagi orang yang tinggal di Palemahan Desa Adat agar dimasukkan menjadi Krama Desa Adat baik yang beragama Hindu maupun yang non Hindu agar bersama-sama mempunyai rasa ikut memiliki dan bertanggung jawab terutama ditinjau dari segi Pawongan dan tidak ikut dalam Parahyangan.

Adapun mengenai Prajuru Adat merupakan alat bagi Desa Adat dalam menyelenggarakan segala urusan rumah tangganya yaitu segala kepentingan Krama/Warga Desa Adat sesuai dengan tujuan yang telah tertuang dalam awig-awig dan keputusan -keputusan yang telah ditetapkan dalam sangkepan/paruman/rapat yang tertuang dalam Perarem.

$$
\begin{aligned}
& \text { c. Palemahan } \\
& \text { Palemahan merupakan unsur mutlak dari }
\end{aligned}
$$


Desa Adat yang luasnya telah ditetapkan dengan batas-batasnya secara nyata. Prajuru Desa Adat melaksanakan otonominya termasuk harta kekayaan yang menjadi milik Desa Adat. Mengenai batas -batas Palemahan ditentukan dalam kesepakatan dengan Desa Adat tetangga dan batas -batasnya yang telah ditetapkan itu dituangkan ke dalam Awig-awig.

Dari uraian tersebut mengenai Parahyangan, Pawongan dan Palemahan dapat ditarik kesimpulan sebagai berikut:

1. Dari adanya Kahyangan Tiga para Krama Desa Adat dapat menyatukan dirinya sebagai penyungsung Pura dengan segala kewajibannya.

2. Ditinjau dari Pawongan para Krama merasa dirinya bersatu yang telah diatur dalam Awig- awig Desa Adat yang harus ditaati.

3. Ditinjau dari Palemahan para Krama yang menempati wilayah Desa Adat merupakan kesatuan yang bulat dan utuh sebagai satu kesatuan.

Desa Adat di Bali telah dapat dibuktikan persatuan dan kesatuannya ditinjau dari beberapa aspek seperti misalnya:

a. Adanya kegotong - royongan Krama Desa dalam menyelesaikan tugas - tugas yang diserahkan dalam hal pelaksanaan upacara agama yang dikenal dengan Panca Yadnya, Bhuta Yadnya dan Resi Yadnya.

b. Adanya kepatuhan Krama Desa Adat terhadap pelaksanaan Awig - awig sehingga terciptanya kekompakan dalam menghadapi permasalahan.

c. Adanya kerukunan sesama Krama Desa yang ditandai dengan rasa saling hormat menghormati dan saling cinta mencintai dalam arti kata luas sehingga terhindar dari perpecahan.

d. Adanya keselarasan, keserasian dan keseimbangan sesame Krama Desa yang ditandai dengan adanya saling asah, asih dan asuh dalam menghadapi berbagai masalah baik datangnya dari dalam maupun luar.

e. Adanya rasa keadilan dalam menciptakan suasana yang aman dan damai tersirat dan tersurat dalam Awig - awig yaitu Tata Pekraman, Tata Parahyangan, Tata Palemahan dan Tata Pawongan.

\section{PENUTUP}

Berdasarkan uraian di atas, dapat ditarik kesimpulan seperti di bawah ini :

1. Kedudukan, fungsi dan peranan Desa Adat semakin kuat berdasarkan Peraturan Daer- ah Provinsi Daerah Tingkat (Tk) I Bali Nomor 23 Tahun 2014 dan Peraturan Menteri Dalam Negeri Nomor 03 Tahun 1997 tentang Pemberdayaan dan Pelestarian serta Pengembangan Adat.

2. Desa Adat yang memiliki Awig- awig baik tertulis maupun tidak tertulis mampu untuk membentuk disiplin para Krama/ Warga secara spontan tanpa ada unsur paksaan dari Kelihan/Kepala Desa Adat sehingga disiplin itu hidup sebagai modal untuk melaksanakan pembangunan di masyarakat sehingga semuanya dapat berjalan dengan lancer dan sukses.

3. Desa sebagai pemersatu Krama dengan jelas dimuat dalam Awig- awig yang terikat dalam Parhyangan, Pawongan dan Palemahan yang merupakan unsur dari Tri Hita Karana.

Disamping itu Desa Adat juga berperan aktif untuk mentransformasikan dan mengaktualisasikan Dharma (kebenaran) dalam kehidupan masyarakat, sehingga dapat menimbulkan rasa aman, damai, tertib dan ada kepastian hukum.

Demikian sekilas tentang eksistensi Desa Adat yang dapat menyatukan Kramanya sehingga terwujudlah disiplin yang hidup dan berkembang di masyarakat Adat dan mampu meningkatkan persatuan dan kesatuan di dalam masyarakat untuk menyukseskan pembangunan di segala bidang.

\section{DAFTAR PUSTAKA}

Pemerintah Daerah Tingkat II Badung, Pedoman Awig-Awig Desa Adat, Penerbit Aksara.

Ruslan Saleh, 1979, Penjabaran Pancasila dan UUD 1945 dalam Perundang -undangan, Jakarta, Aksara Baru.

Soepomo, 1977, Mengenal Desa, Gerak dan Pengelolaannya, Cetakan Pertama, PT Internusa.

Soetardjo Kartohadikoesoemo, 1984. Desa, Cetakan Pertama, Jakarta, Balai Pustaka.

Surpha, I Wayan, 2004, Eksistensi Desa Adat dan Desa Dinas di Bali. Denpasar, Pustaka Bali Post.

Tjokorda Raka Dherana, 1974, Pembinaan Awig-Awig dalam Tertib Masyarakat (Prasarana dalam Seminar Hukum I), 